\title{
DEVELOPMENT OF THE SPINE FOLLOWING PINEALECTOMY IN GROWING RATS
}

\author{
A. NEČAS, M. DVOŘÁK \\ Clinic of Surgery and Orthopedics, University of Veterinary and Pharmaceutical Sciences, Brno, \\ Czech Republic \\ Received December 14, 1998 \\ Accepted January 14, 1999
}

Abstract

Nečas A., M. Dvořák: Development of the Spine Following Pinealectomy in Growing Rats. Acta vet. Brno 1999, 68: 31-39.

Idiopathic scoliosis is the most frequent spine deformity in the frontal plane in man. Etiology of the disease, despite of long-lasting efforts to disclose it, remains unknown. This experimental study was aimed at assessing the spine development in growing rats following pinealectomy and drawing conclusions concerning the pathology of idiopathic scoliosis in man.

The authors evaluated the development of scoliosis in 22 rats (Rattus norvegicus $v$. alba $\mathrm{f}$. domestica) following surgical pinealectomy. Rats were operated on after intraperitoneal anesthesia at 3 to 5 weeks of age. Incidence of scoliosis was radiographically determined 8 and 16 weeks after the surgery. The rats were then euthanized and the excision of corpus pineale was confirmed histologically by an independent pathologist who examined their isolated brains. In all, 8 adult rats in a good state of health served as controls for determining the normal physiological spine curvature.

More rapid growth was observed in the experimental group of 22 rats after pinealectomy at the age of 3 to 5 weeks. The mean body weight after four months of age reached $425 \mathrm{~g}$. Cervicothoracic lordosis (from C2 to T7) and thoracolumbar kyphosis (from T7 to S1) measured $-40^{\circ}$ and $+25^{\circ}$ on average, respectively. Scoliosis was found in 5 rats (four males and one female), i.e. $22.7 \%$ of cases out of 22 animals evaluated at the end of the study. We found left-hand curvatures four times with the apex once between T4 - T5, once between T12 - T13 and twice between L3 - L4. In the case of one right-hand curvature it was between T10 and T11. The mean scoliosis value was $10.8^{\circ}$ (from $9^{\circ}$ to $14^{\circ}$ ). There was no scoliosis found in the control group of 8 healthy adult rats. Statistical evaluation of obtained results was performed. Evaluating the occurrence of scoliosis in experimental animals in comparison with the control group using Fisher's test we found no statistically significant relation to pinealectomy at the $5 \%$ level of significance. Student's $t$-test proved statistically significant differences $(\mathrm{p}<0.01)$ between both groups as far as the thoracolumbar kyphosis was concerned. Results of the $t$-test were not significant for cervicothoracic lordosis.

Our results indicate that the pineal body may play a role in the origin and development of idiopathic scoliosis in rats, though we cannot exclude the influence of peroperative bleeding, brain hypoxia or metabolic effects of anaesthetics. These factors may also influence the curvature of the thoracolumbar kyphosis.

Scoliosis, spine, pinealectomy, rat

Idiopathic scoliosis is the most frequent structural spine deformity in its frontal plane. This disorder originates and gradually develops during the period of growth of children with initially straight spine. Three types of idiopathic scoliosis can be distinguished according to the onset of the first signs of spine curving: 1) infantile scoliosis encountered during the first three years of life, 2) juvenile scoliosis from three years of age to puberty and 3) adolescent idiopathic scoliosis from the beginning of puberty to growth cessation.

The whole spine except the neck may be affected. Great attention is at present paid both to the early diagnosis and therapy of this disorder due to its increased frequency of

Address for correspondence:

MVDr. Alois Nečas, Ph.D.

Clinic of Surgery and Orthopedics

Crmaceutical Sciences

Palackého 1-3, 61242 Brno, Czech Republic

Phone: +420602742484

E-mail: necas@eurosat.cz 
occurrence in the early youth of man. The diagnosis is based on a careful clinical and radiographic examination of the spine. On the basis of such results it is possible to make a prognosis and propose a precise plan of therapy. In growing individuals with a moderate deformity (from $25^{\circ}$ to $40^{\circ}$ according to Cobb) (Cobb 1948) conservative therapeutic methods are chosen. Many authors, however, proved that conservative therapy influences the development of scoliosis in a smaller number of patients than previously expected (Hopf et al. 1998; Chaloupka et al. 1992; Lonstein and Winter 1994; Nooman et al. 1996). There is indicated a surgical treatment consisting in the correction of the position of vertebrae with subsequent internal fixation in individuals with a marked spine deformity (from $40^{\circ}$ to $50^{\circ}$ according to Cobb).

The success of therapy is limited by the fact that the etiology of idiopathic scoliosis remains unknown. Such animals as monkeys (Pincott et al. 1984), rabbits (Barrios et al. 1987; Carpintero et al. 1997; Pal 1991; Pal et al. 1991; Suk et al. 1989), rats (Barrios and Arrotegui 1992), and chickens (Coillard and Rivard 1996; Kanemura et al. 1997; Machida et al. 1993; Machida et al. 1996; Machida et al. 1994; Machida et al. 1997; W ang et al. 1997) were used for experiments aimed at the search for the etiology of scoliosis. From these experimental studies it is clear that idiopathic scoliosis is of multifactorial origin and development. There are several hypotheses concerning the etiology of idiopathic scoliosis described in the literature. Genetic (Archer and Dickson 1985; Goldberg et al. 1997; Keim 1976; Kesling and Reinker 1997; Le Blanc et al. 1997; Millner and Dickson 1996; Wynne-Davies et al. 1982), metabolic (Bradford et al. 1977; Worthington and Shambaugh 1993), hormonal (Bagnall et al. 1996; Coillard and Rivard 1996; Machida et al. 1996), skeletal (Grivas et al. 1991; Manganiello 1987; Millner and Dickson 1996; Sevastik et al. 1984; Tomaschewski 1989), myogenic (Karski 1996), neuromuscular (Keim 1976), and neurogenic (Barrack et al. 1988; Depotter et al. 1987; Herman et al. 1985; Keesen et al. 1992; Lewonowski et al. 1992; Machida et al. 1993; Machida et al. 1994; Maiocco et al. 1997; Mochida et al. 1993; O’Beirne et al. 1989; Roth 1996; Royo-Salvador 1996; Sahlstrand et al. 1979; Samuelsson et al. 1991; Wyatt et al. 1986; Zadeh et al. 1995) disorders are mentioned as main etiological factors. The importance of heredity was confirmed only in clinical cases and several experimental and clinical studies confirmed the influence of neurological dysfunctions localised in the central nervous system as well.

Apart from experiments on animals, computer modelling is used in the study of idiopathic scoliosis (Murray and Bulstrode 1996).

In the 1990's the attention of scientists concentrated on the possibility of connection between the origin and development of idiopathic scoliosis and low amounts of serotonin which is produced in corpus pineale. Scientists performed surgical removal of corpus pineale in young chickens (Wang et al. 1997; Kanemura et al. 1997; Machida et al. 1994, 1996; Coillard and Rivard 1996) and their results supported the theory that serotonin plays a role in the development of idiopathic scoliosis.

The aim of this experimental study

Since experiments on chickens are of limited value in searching for the etiology of idiopathic scoliosis in man, it was our goal to study the influence of pinealectomy during body growth of some mammalian species on the development of spine.

\section{Materials and Methods}

Laboratory Norway rats (Rattus norvegicus v. alba f. domestica - Wistar albino rat) were selected as model animals. Ethics Committee Approval (September 19,1997) was given to conduct the study according the standard protocol. The control group consisted of 8 healthy adult rats in which we determined the normal physiological spine curvature. Cervicothoracic lordosis and thoracolumbar kyphosis were measured. 
Both males and females were included in the experiment. The pineal body was removed surgically in 24 rats at the age of 3 to 5 weeks when the individuals reached the mean body weight of $70 \mathrm{~g}$ (varying from $40 \mathrm{go} 120 \mathrm{~g}$ ). There was no medication administered to the rats after the surgical procedure and laterolateral and dorsoventral radiographs of spine were taken two times. The first radiographic examination was performed 8 weeks and the second one 16 weeks after pinealectomy. Using radiographs taken 16 weeks after the surgery we measured the curves of cervicothoracic lordosis and thoracolumbar kyphosis and according to methods by Cobb (1948) we determined the degree of prospective scoliosis. Scoliosis cases over $8^{\circ}$ were only considered to be clinically important (Barrios and Arrotegui 1992). For the purpose of radiographic examination the rats were anesthetized using halothane in an inhalation chamber and after the second radiography they were euthanized. Then their brain was removed, fixed by $10 \%$ formaldehyde and evaluated by an independent histopathologist to confirm the pineal body removal.

Surgical procedures were performed under intraperitoneal anesthesia (diazepam at the dose of $15 \mathrm{mg} / \mathrm{kg}$ in combination with $5 \%$ ketamine $60 \mathrm{mg} / \mathrm{kg}$ ). Dorsocaudal approach to the pineal body during the surgery of the first four rats was used. At first, skin was incised in lenght about $1.5 \mathrm{~cm}$ in the median line of the dorsocaudal cranium right after confluens sinuum and then a circular opening of about $3 \mathrm{~mm}$ diameter in the cranium with help of a special burr under continuous cooling by saline solution was made. Dura mater was perforated in the length of $1-2 \mathrm{~mm}$ using a hypodermic needle of $0.7 \mathrm{~mm}$ diameter. After that, the pineal body was removed using anatomical tweezers. Reliability of this surgical procedure was verified before the start of the experiment by histopathological examination of brains from three cadavers of rats. During the surgical procedure we encountered massive bleeding in three rats and had to take immediately quite exacting steps for resuscitation. Because of these problems we changed the surgical procedure. The modification consisted in preparation of the subcutis of the caudodorsal area of cranium from the left and cranial opening in the angle between sinus sagittalis and sinus transversus on the left. Bleeding was minimised and due to proper cooling of the bone burr during cutting of the cranium there was no need for resuscitation. The surgical wound was only closed by simple interrupted suture of the skin using non-absorbable monofilament material. Recovery from anesthesia was quick, mostly within 30 minutes, and without motor dysfunctions.

Statistical significance of our results was evaluated using Fisher's test (relationship between the development of scoliosis and pinealectomy) and Mann-Whitney $U$-test (differences in the angle of scoliosis of experimental and control rats). The curves of cervicothoracic lordosis and thoracolumbar kyphosis in both groups were evaluated by Student's $t$-test. Statistical analyses were done using Stat plus 1.10 (Matoušková et al. 1992).

\section{Results}

Pinealectomy was completed successfully in all 24 rats. It was not necessary to administer any analgesic agents or antibiotics to the rats. There were no healing complications of surgical wounds. The intraperitoneal anesthesia (diazepam in the dose of $15 \mathrm{mg} / \mathrm{kg}$ in combination with $5 \%$ ketamine in the dose of $60 \mathrm{mg} / \mathrm{kg}$ ) proved to be quite adequate for this surgical procedure. Time needed for the onset of surgical stage of anesthesia (from the intraperitoneal injection to the start of operation) was 5 to 11 minutes, i.e. 7 minutes on average. The surgical procedure lasted 5 to 30 minutes (it was 30 minutes at the beginning of this experiment, and then it gradually took less time) with the average of 13.5 minutes. There was no need to prolong the anesthesia by further administration of anesthetics during the procedure.

During the first radiographic examination two rats died due to halothane inhalation anesthesia. Therefore, only 22 individuals (15 males and 7 females) could be used for the final evaluation of the study. Radiographs taken 8 weeks after the surgery served only as control of the spine development and were not used for any measurements. It was the second radiographic examination 16 weeks after the surgery that was used to evaluate the development of scoliosis. The rats were euthanized after this examination. At that time, their body weight amounted to $425 \mathrm{~g}$ on average $(250-600 \mathrm{~g})$, with males being considerably larger than females. We found much quicker somatic and sexual maturation in the experimental group as compared to controls. This fact enabled active reproduction in two females. The mean body weight of laboratory Norway rats described in literature is $400 \mathrm{~g}$.

The cervicothoracic lordosis measured using the Cobb's method from the second to the seventh cervical vertebrae in pinealectomised rats was $-26^{\circ}$ to $-48^{\circ}$, i.e. $-40^{\circ}$ on average. The mean value of the thoracolumbar kyphosis in pinealectomised rats, measured from the seventh thoracic vertebra to the cranial border of the sacral bone, was $+25^{\circ}$. Individual values varied from $+16^{\circ}$ to $+33^{\circ}$. 
Values of the cervicothoracic lordosis in the control group of 8 healthy adult individuals, measured before the experiment, varied from $-39^{\circ}$ to $-63^{\circ}$, with the average of $-48.3^{\circ}$. The thoracolumbar kyphosis in the control group was equal to $+41^{\circ}$ to $+54^{\circ}$, with the average of $+48^{\circ}$. There was $0^{\circ}$ scoliosis found in all 8 control rats.

The mean scoliosis in the group of all 22 pinealectomised rats amounted to $5.4^{\circ}$. Such scoliosis cases in which we found values from $9^{\circ}$ to $14^{\circ}$, i.e. $10.8^{\circ}$ on average, were clinically important. They were found in 5 rats ( 4 males and 1 female), i.e. in $22.7 \%$ of all cases. The curvature aimed to the left (Plate XII, Fig. 1) in four cases. The apex of the curves in lefthand deviations was situated once between T4 and T5, once between T12 and T13, and twice between L3 and L4. In the case of right-hand curvature it was between T10 and T11. The curvatures were heterogeneous, of different length and with apices in various parts of the spine. All the curvatures were non-structural and without rotation of vertebrae.

The excision of corpus pineale was confirmed by an independent histopathologist after euthanasia of experimental rats.

There are surveyed the indices monitored during the experiment in the group of 17 individuals without scoliosis after pinealectomy and in the group of 5 rats with measured scoliosis in Tables 1 and 2, respectively.

Table 1

The group of rats without scoliosis after the removal of the pineal body

\begin{tabular}{|c|c|c|c|c|c|c|c|c|c|}
\hline 1 & 2 & 3 & 4 & 5 & 6 & 7 & 8 & 9 & 10 \\
\hline No & Sex & g & $\begin{array}{l}\text { Time } \\
\text { min. }\end{array}$ & x-ray & curv. & x-ray & curv. & $\begin{array}{lll}\mathrm{C} 2 & \mathrm{~T} 7 & \mathrm{~S} 1\end{array}$ & g \\
\hline 1. (2) & $\mathrm{M}$ & 40 & 30 & $0^{\circ}$ & & $0^{\circ}$ & & $-35^{\circ}+22^{\circ}$ & 500 \\
\hline 2. (4) & $\mathrm{F}$ & 50 & 22 & T13 $5^{\circ}$ L6 & $\mathrm{dx}$ & $0^{\circ}$ & & $-41^{\circ}+28^{\circ}$ & 250 \\
\hline 3. (7) & M & 70 & 20 & T3 $\quad 4^{\circ} \mathrm{L} 2$ & Sin & T3 $6^{\circ} \mathrm{L} 2$ & Sin & $-30^{\circ}+28^{\circ}$ & 600 \\
\hline 4. (8) & $\mathrm{M}$ & 70 & 15 & T11 $6^{\circ}$ L6 & Sin & $0^{\circ}$ & & $-37^{\circ}+27^{\circ}$ & 600 \\
\hline 5. (10) & $\mathrm{M}$ & 60 & 15 & T11 19 L6 & Sin & T12 $6^{\circ} \mathrm{L} 6$ & Sin & $-48^{\circ}+25^{\circ}$ & 350 \\
\hline 6. (13) & $\mathrm{M}$ & 70 & 13 & T13 $5^{\circ} \mathrm{L} 6$ & Dx & T9 $4^{\circ} \mathrm{L} 6$ & Sin & $-35^{\circ}+27^{\circ}$ & 450 \\
\hline 7. (14) & $\mathrm{F}$ & 70 & 10 & $0^{\circ}$ & & T5 $4^{\circ} \mathrm{L} 2$ & Sin & $-38^{\circ}+28^{\circ}$ & 350 \\
\hline 8. (15) & $\mathrm{M}$ & 80 & 16 & T9 $4^{\circ} \mathrm{L} 6$ & Sin & T9 $8^{\circ}$ L6 & Sin & $-33^{\circ}+19^{\circ}$ & 500 \\
\hline 9. (16) & $\mathrm{M}$ & 60 & 12 & $\mathrm{~T} 1211^{\circ} \mathrm{L} 6$ & Sin & $\mathrm{T} 126^{\circ} \mathrm{L} 6$ & Sin & $-45^{\circ}+26^{\circ}$ & 350 \\
\hline 10. (19) & $\mathrm{M}$ & 90 & 16 & $0^{\circ}$ & & $0^{\circ}$ & & $-26^{\circ}+16^{\circ}$ & 450 \\
\hline 11. (21) & $\mathrm{F}$ & 90 & 13 & $0^{\circ}$ & & L1 $7^{\circ}$ L6 & Dx & $-48^{\circ}+19^{\circ}$ & 350 \\
\hline 12. (22) & M & 120 & 15 & $0^{\circ}$ & & T10 $6^{\circ}$ L6 & Dx & $-48^{\circ}+27^{\circ}$ & 400 \\
\hline 13. (23) & $\mathrm{M}$ & 120 & 15 & C6 $6^{\circ} \mathrm{T} 10$ & Sin & C6 $3^{\circ} \mathrm{T} 10$ & Dx & $-41^{\circ}+21^{\circ}$ & 450 \\
\hline 14. (25) & M & 60 & 8 & T3 $3^{\circ} \mathrm{T} 12$ & Dx & T7 $5^{\circ} \mathrm{L} 2$ & Sin & $-42^{\circ}+33^{\circ}$ & 500 \\
\hline 15. (26) & $\mathrm{M}$ & 60 & 9 & $0^{\circ}$ & & $0^{\circ}$ & & $-41^{\circ}+31^{\circ}$ & 450 \\
\hline 16. (30) & $\mathrm{F}$ & 55 & 6 & $\mathrm{~T} 134^{\circ} \mathrm{L} 6$ & Dx & $\mathrm{C} 65^{\circ} \mathrm{T} 13$ & Dx & $-46^{\circ}+18^{\circ}$ & 350 \\
\hline 17. (32) & $\mathrm{F}$ & 50 & 8 & $\mathrm{~T} 7 \quad 6^{\circ} \mathrm{L} 1$ & Sin & T10 $4^{\circ}$ L6 & Dx & $-36^{\circ}+20^{\circ}$ & 300 \\
\hline
\end{tabular}

Legend:

$1^{\text {st }}$ column: rank number, experimental individual's number in parentheses

$2^{\text {nd }}$ column: sex (M-male, F-female)

$3^{\text {rd }}$ column: body weight at the time of operation in grams

$4^{\text {th }}$ column: duration of the operation in minutes

$5^{\text {th }}$ column: caudoventral radiographic view 2 months after the operation, in degrees according to Cobb (T-thoracic, L-lumbar, number of the vertebra)

$6^{\text {th }}$ column: convexity of the curvature (dx-right hand, sin-left hand)

$7^{\text {th }}$ column: caudoventral radiographic view 4 months after the operation, in degrees according to Cobb (see the $5^{\text {th }}$ column)

$8^{\text {th }}$ column: convexity of the curvature (see the $6^{\text {th }}$ column)

$9^{\text {th }}$ column: laterolateral radiograph of the spine in degrees according to Cobb (terminal vertebrae are C2-i.e. the second cervical one, T7- i.e. the seventh thoracic one, S1 - i.e. the cranial border of the sacral bone). The sign minus indicates lordosis, plus kyphosis

$10^{\text {th }}$ column: body weight in grams four month after the operation 
No scoliosis case was found in the group of 8 control healthy adult animals. There were 5 cases of scoliosis found $(22.7 \%)$ in the group of 22 evaluated rats which were subjected to the surgical procedure. Evaluating the dependence of scoliosis on pinealectomy by the Fisher's test there were no significant findings on the 5\% level. Because the number of cases was low, it is necessary to examine the occurrence of scoliosis in a much more numerous group of experimental rats. Using the Mann-Whitney $U$-test to evaluate the differences in the angle measured according to $\operatorname{Cobb}\left(0^{\circ}\right.$ in the control group and $5.4^{\circ}$ in the experimental one, on average) we found significant differences $(\mathrm{p}<0.01)$. Significant differences between both groups were also found in curves of the thoracolumbar kyphosis $(p<0.01)$ by the Student's $t$-test. As far as the cervicothoracic lordosis is concerned, the $t$-test was not significant. Interpreting such results we have to bear in mind high variability found in this index.

Table 2

The group of rats with scoliosis of $9^{\circ}$ and more after the removal of the pineal body

\begin{tabular}{|c|c|c|c|c|c|c|c|c|c|}
\hline 1 & 2 & 3 & 4 & 5 & 6 & 7 & 8 & 9 & 10 \\
\hline No & Sex & $\mathrm{g}$ & $\begin{array}{l}\text { Time } \\
\text { min. }\end{array}$ & x-ray & curv. & x-ray & curv. & C2 277 S1 & g \\
\hline 1. (18) & M & 70 & 15 & $\mathrm{~T} 110^{\circ} \mathrm{L} 2$ & Dx & L1 L6 $14^{\circ}$ & Sin & $-45^{\circ}+30^{\circ}$ & 500 \\
\hline 2. (20) & M & 90 & 15 & $\mathrm{~T} 133^{\circ} \mathrm{L} 6$ & Sin & T6 L6 $10^{\circ}$ & Sin & $-42^{\circ}+19^{\circ}$ & 450 \\
\hline 3. (24) & $\mathrm{M}$ & 60 & 12 & $0^{\circ}$ & & L1 L6 $10^{\circ}$ & Sin & $-43^{\circ}+31^{\circ}$ & 450 \\
\hline 4. (28) & $\mathrm{F}$ & 50 & 7 & $\mathrm{~T} 105^{\circ} \mathrm{L} 6$ & Sin & C6 T10 $11^{\circ}$ & Sin & $-45^{\circ}+33^{\circ}$ & 300 \\
\hline 5. (29) & M & 50 & 5 & $\mathrm{~T} 23^{\circ} \mathrm{T} 12$ & Dx & T2 L6 $9^{\circ}$ & Dx & $-37^{\circ}+25^{\circ}$ & 450 \\
\hline
\end{tabular}

Legend:

$1^{\text {st }}$ column: rank number, experimental individual's number in parentheses

$2^{\text {nd }}$ column: sex (M-male, F-female)

$3^{\text {rd }}$ column: body weight at the time of operation in grams

$4^{\text {th }}$ column: duration of the operation in minutes

$5^{\text {th }}$ column: caudoventral radiographic view 2 months after the operation, in degrees according to Cobb (T-thora-

cic, L-lumbar, number of the vertebra)

$6^{\text {th }}$ column: convexity of the curvature (dx-right hand, sin-left hand)

$7^{\text {th }}$ column: caudoventral radiographic view 4 months after the operation, in degrees according to Cobb (see the

$5^{\text {th }}$ column)

$8^{\text {th }}$ column: convexity of the curvature (see the $6^{\text {th }}$ column)

$9^{\text {th }}$ column: laterolateral radiograph of the spine in degrees according to Cobb (terminal vertebrae are C2-i.e. the second cervical one, T7- i.e. the seventh thoracic one, S1 - i.e. the cranial border of the sacral bone). The sign

minus indicates lordosis, plus kyphosis

$10^{\text {th }}$ column: body weight in grams four month after the operation

\section{Discussion}

When selecting a suitable animal species for our experimental study, it was necessary to consider its phylogenetic classification, duration of somatic maturation and demands of its breeding. After considering the above-mentioned aspects, laboratory Norway rats belonging to the mammalian class were chosen. They mature quickly, are not so demanding on the conditions of breeding and are very hardy. What is disadvantageous is the fact that they, contrary to man, do not move in an upright position, but are quadrupedal. The age of rats used for the experiment was chosen with regards to the requirement of performing pinealectomy as soon after the birth as possible in order to study its influence on the development of the animals. Brain in rats reaches maturation comparable to healthy human newborn brain tissue at the age of 10 days. Sexual maturation begins on the $35^{\text {th }}$ day of life in rats and they mature completely at the age of 90 days (Mareš 1991). For the experiment rats at the age of 3 to 5 weeks were chosen, i.e. the age when quick somatic growth starts and the individuals are not dependent nutritionally on mother's milk. To our knowledge, there 
have not been published more than one experimental study devoted to the development of scoliosis in rats after surgical removal of the pineal body (Dubous set et al. 1983) as yet.

The kind of anesthesia and the surgical procedure were selected on the basis of compilation of published data and our own experiences obtained during preparation for the experiment using control animals. The anesthesia chosen was easy to perform, inexpensive, quickly induced and with its length and depth of sufficient quality.

The animals were kept under conditions that correspond with species requirements. The radiographic examination in 8 weeks after the surgery, i.e. during growth, was done only for the purpose of control evaluation of spine development. For definitive diagnosis and scoliosis measurements to be done, it was necessary to evaluate radiographs taken 16 weeks after the procedure, i.e. after the end of growth in the experimental rats. Selection of the surgical procedure (pinealectomy) was based on following considerations. Affects in the muscles, nervous radices, vertebrae or ribs lead to the development of scoliosis of various degree. There were not, however, found primary defects in these tissues causing scoliosis. Injuries of the central nervous system on various levels lead also to the development of scoliosis. The development of scoliosis was best described in chickens after pinealectomy (Coillard and Rivard 1996; Kanemura et al. 1997; Machida et al. 1993; Machida et al. 1996; Machida et al. 1994; Wang et al. 1997). In chickens it is possible to explain the development of scoliosis by extraordinary numerous melatonin receptors (in the brain stem, gray matter of the spinal cord, especially in the sacral area) (W an and Pang 1994). In other animal species these receptors are found in limited numbers in thalamus, hypothalamus and hypophysis (Fang et al. 1990; Laitinen et al. 1990; Laitinen and Saavedra 1990; Utiger 1992). Fagan et al. (1998) on the basis of their study of melatonin levels in stable and progressive idiopathic scolioses excluded the possibility of their therapy using melatonin. The melatonin model describing the origin of scoliosis in chickens, in some author's opinion (Machida et al. 1993; Machida et al. 1994; Machida et al. 1997), may aid to discover similar receptors influencing decompensation of postural functions which lead to the development of scoliosis in man. Contrary to this opinion, negligible importance of experimental studies using chickens in the search for the etiology of human idiopathic scoliosis is witnessed by different structure of the brain cortex in addition to the above-mentioned facts concerning melatonin receptors and different numbers of vertebrae (Coillard and Rivard 1996).

Only a few studies on the influence of pinealectomy were done using other animal species. Stebbins (1960) did not find scoliosis in lizards and the same conclusion was obtained by Dubous set et al. (1983) in the only study which concerned this surgical procedure in rats. Only a moderate scoliosis $\left(9^{\circ}\right.$ to $\left.14^{\circ}\right)$ developed in a small number of our experimental rats $(22.7 \%)$. We encountered, however, peroperative bleeding which might be causing the development of scoliosis.

The mean body weight of adult rats mentioned in published sources is equal to $400 \mathrm{~g}$. Females are smaller and of lower weight than males. In our experiment we found quicker maturation and higher mean body weight in pinealectomised rats. This fact has not been described in scientific papers yet. It may be explained by impairing hormonal functions and the so-called biological clock.

In healthy adult rats we measured the cervicothoracic lordosis in values from $-39^{\circ}$ to $-63^{\circ}$, i.e. $-48.3^{\circ}$ on average; and the thoracolumbar kyphosis from $+41^{\circ}$ to $+54^{\circ}$, i.e. $+48.0^{\circ}$ on average (our own findings). The cervicothoracic lordosis in pinealectomised rats amounted to $-26^{\circ}$ to $-48^{\circ}$, i.e. $-40^{\circ}$ on average. The mean thoracolumbar kyphosis in pinealectomised rats was equal to $+25^{\circ}$. The individual values varied from $+16^{\circ}$ to $+33^{\circ}$.

Evaluating our experimental results we have to consider the possibility that other factors, such as injuries to the surrounding brain tissue during the procedure (Chaloupka 1998), 
brain hypoxia, and metabolic-toxic effects of anesthetics, might have participated in the development of scoliosis. On the other hand, in experimental individuals without scoliosis development we may suppose compensatory mechanisms outweighing the development of spinal changes.

\section{Vliv odstranění corpus pineale na vývoj páteře u rostoucích potkanů}

Idiopatická skolióza je u člověka nejčastější zakřivení páteře ve frontální rovině. Příčina idiopatické skoliózy přes dlouhodobé úsilí o její odhalení zůstává neznámá. Cúlem experimentální práce bylo zhodnotit vývoj páteře rostoucích potkanů po odstranění corpus pineale a z výsledků vyvodit závěry pro patologii idiopatické skoliózy u lidí.

Autoři hodnotili rozvoj skoliózy u 22 krys (Rattus norvegicus v. alba f. domestica) po chirurgickém odstranění corpus pineale.Potkany byly operovány $\mathrm{v}$ intraperitoneální anestézii ve stáří 3 až 5 týdnů. Výskyt skoliózy byl hodnocen na základě rentgenologického vyšetření za 8 a 16 týdnů po operaci. Poté byly potkany usmrceny a na vypreparovaném mozku bylo nezávislým histologem potvrzeno vyjmutí corpus pineale. Jako kontrolní skupina sloužilo 8 zdravých dospělých potkanů, u nichž bylo stanoveno fyziologické zakřivení páteře.

U skupiny 22 potkanů po odstranění corpus pineale ve věku 3 až 5 týdnů autoři zaznamenali rychlejší růst. Průměrná hmotnost za 4 měsíce dosáhla 425 g. Cervikotorakální lordóza $(\mathrm{C} 2$ T7) měřila průměrně $-40^{\circ}$, torakolumbální kyfóza (mezi T7 a S1) měřila v průměru $+25^{\circ}$. Skolióza byla zjištěna u 5 potkanů (4 samců), tj. ve $22,7 \%$ případů. Čtyřikrát šlo o křivku levostrannou s vrcholem mezi T4 - T5, T12 - T13, a dvakrát mezi L3 - L4. Skolióza měla v průměru $10,8^{\circ}\left(9^{\circ}\right.$ až $\left.14^{\circ}\right)$. V kontrolní skupině 8 zdravých dospělých potkanů jsme nezjistili žádného jedince se skoliózou. Ve skupině 22 operovaných potkanů jsme zjistili skoliózu v 5 př́ipadech $(22,7 \%)$. Při hodnocení závislosti výskytu skoliózy na pinealektomii Fisherovým testem jsme neprokázali závislost na 5\% hladině významnosti. Statisticky významné rozdíly mezi oběma skupinami jsme zjistili v křivkách torakolumbální kyfózy $(\mathrm{p}<0,01)$ Studentovým $t$-testem. V případě cervikotorakální lordózy byl $t$-test neprůkazný.

Pinealektomie spolu s lokalizovanou ischémií a peroperačním krvácením mohou být u potkanů př́ičinou skoliózy. Tyto faktory mohou ovlivnit i křivku torakolumbální kyfózy.

\section{References}

ARCHER, I. A., DICKSON, R. A. 1985: Stature and idiopathic scoliosis. A prospective study. J. Bone Joint Surg. 67: $185-188$

BAGNALL, K. M., RASO, V. J., HILL, D. L. et al. 1996: Melatonin Levels in Idiopathic Scoliosis. Diurnal and Nocturnal Serum Melatonin Levels in Girls With Adolescent Idiopathic Scoliosis. Spine. 21: 1974-1978

BARRACK, R. L., WYATT, M. P., WHITECLOUD, T. S., BURKE, S. W., ROBERTS, J., M. BRINKER, M. R. 1988: Vibratory hypersensitivity in idiopathic scoliosis. J. Pediatr. Orthop. 8: 389- 395

BARRIOS, C., ARROTEGUI, J. I. 1992: Experimental kyphoscoliosis induced in rats by selective brain stem damage. International Orthopaedics (SICOT). 16: 146-151

BARRIOS, C., TUNON, M. T., DE SALIS, J. A., et al. 1987: Scoliosis Induced by Medullary Damage: An Experimental Study in Rabits. Spine.12: 433-439

BRADFORD, D. S., OEGEMA, T. R., BROWN, D. M. 1977: Studies of skin fibroblasts of patients with idiopathic scoliosis. Clin. Orthop. 126:111-118

CARPINTERO, P., MESA, M., GARCIA, J., CARPINTERO, A. 1997: Scoliosis Induced by Asymmetric Lordosis and Rotation. An experimental Study. Spine 22: 2202-2206

COBB, J. R. 1948: Outline for the study of scoliosis. AAOS INST. Course Lect. 5, p. 261

COILLARD, C., RIVARD, C. H. 1996: Vertebral deformities and scoliosis. Eur. Spine J. 5: 91-100

DEPOTTER, J., RIGAULT, P., POULIQUEN, J. C., PADOVANI, J. P., HIRSCH, J. F., REGNIER, D., BESSON, G., TOUZET, P., GUINGAND, O., GUYONVARCH, G. 1987: Syringomyelie et scoliose chez l'enfant et l'adolescent. A propos de 14 cas. Rev. Chir. Orthop. 73: 203-212

DUBOUSSET, J., QUENEAU, P., THILLARD, M. J. 1983: Experimental scoliosis induced by pineal and diencephalon lesions in young chickens: Its relation with clinical findings in scoliosis. Orthopaedic Transactions 7: 7 
FAGAN, A. B., KENNAWAY, D., J. SUTHERLAND, A. D. 1998: Total 24-hour melatonin secretion in adolescent idiopathic scoliosis. A case-control study. Spine 23: 41-46

FANG, J. M., SOUCIAK, J. A., KRAUSE, D. N., DUBOCOVICH, M. L. 1990: Localisation and characterisation of melatonin binding sites in C3H/HeN and C57/BL6J mice. Pharmacologist 32: 144

GOLDBERG, C. J., FOGARTY, E. E., MOORE, D. P., DOWLING, F. E.1997: Scoliosis and Developmental Theory. Adolescent Idiopathic Scoliosis. Spine 22: 2228-2238

GRIVAS, T. B., BURWELL, R. G., PURDUE, M., WEBB, J. K., MOULTON, A. 1991: A segmental analysis of thoracic shape in chest radiographs of children. Changes related to spinal level, age, sex, side and significance for lung growth and scoliosis. J. Anat. 178: 21-38

HERMAN, R., MIXON, J., FISHER, A., MAULUCCI, R., STUYCK, J. 1985: Idiopathic scoliosis and the central nervous system: A motor control problem. Spine 10: 1-14

HOPF, CH., SCHEIDECKER, M., STEFFAN, K., BODEM, F., EYSEL, P. 1998: Gait analysis in idiopathic scoliosis before and after surgery: a comparison of the pre- and postoperative muscle activation pattern. Eur. Spine J. 7: 6-11

CHALOUPKA, R. 1998: The influence of sensorymotor cortical area damage on the development of the spine experimental study. Habilit. Thesis, Masaryk University, Brno, 119 p.

CHALOUPKA, R., VLACH, O., SUŠKEVIČ, I., KALA, B. 1992: Prognóza vývoje idiopatických hrudních křivek a jejich ovlivnění ortézou. Referát. výběr ortop. a traumatol. 1-2: 6-8

KANEMURA, T., KAWAKAMI, N., DEGUCHI, M., et al. 1997: Natural course of experimental scoliosis in pinealectomized chickens. Spine. 22: 1563-1567

KARSKI, T. 1996: Contractures and growth disturbances in the hip and pelvis as the cause of idiopathic scoliosis. Biomechanical considerations. Chir. Narzadow Ruchu Ortop. Pol. 61: 143-150

KEESEN, W., CROWE, A., HEARN, M. 1992: Proprioceptive accuracy in idiopathic scoliosis. Spine. 17: 149-155

KEIM, H. 1976: The adolescent spine. New York. Grune and Stratton. 460 p.

KESLING, K. L., REINKER, K. A. 1997: Scoliosis in Twins. A Meta-analysis of the Literature and Report of Six Cases. Spine. 22: 2009-2015

LAITINEN, J. T., FLUGGE, G., SAAVEDRA, J. M. 1990: Characterisation of melatonin receptors in the rat area postrema: Modulation of affinity with cations and guanine nucleotides. Neuroendocrinology. 51: 619-624

LAITINEN, J. T., SAAVEDRA, J. M. 1990: Characterisation of melatonin receptors in the rat suprachiasmatic nuclei: Modulation of affinity with cations and guanine nucleotides. Endocrinology 126: 2110-2115

LEBLANC, R., LABELLE, H., CHARLES-HILAIRE, R., POITRAS, B. 1997: Relation between adolescent idiopathic scoliosis and morphologic somatotypes. Spine 22: 2532-2536

LEWONOWSKI, K., KING, J. D., NELSON, M. D. 1992: Routine use of magnetic resonance imaging in idiopathic scoliosis patients less than eleven years of age. Spine 17: (6 Suppl): S109-S116

LONSTEIN, J. E., WINTER, R. B. 1994: The Milwaukee brace for the treatment of adolescent idiopathic scoliosis. A review of one thousand and twenty patients. J. Bone Joint Surg. Am. 76: 1207- 1221

MACHIDA, M., DUBOUSSET, J., IMAMURA, Y., et al. 1993: An experimental study in chickens for the pathogenesis of idiopathic scoliosis. Spine 18: 1609-1615

MACHIDA, M., DUBOUSSET, J., IMAMURA, Y., et al. 1996: Melatonin. A possible role in pathogenesis of adolescent idiopathic scoliosis. Spine 21: 1147-1152

MACHIDA, M., DUBOUSSET, J., IMAMURA, Y., et al. 1994: Pathogenesis of idiopathic scoliosis: SEPs in chicken with experimentally induced scoliosis and in patients with idiopathic scoliosis. Journal of Pediatric Orthopaedics 14: 329-335

MACHIDA, M., MIYASHITA, Y., MURAI, I., et al. 1997: Role of serotonin for scoliotic deformity in pinealectomized chicken. Spine 22: 1297-1301

MAIOCCO, B., DEENEY, V., F., COULON, R., PARKS, P., F. 1997: Adolescent idiopathic scoliosis and the presence of spinal cord abnormalities. Preoperative Magnetic Resonance Imaging Analysis. Spine 22: 2537 2541

MANGANIELLO, A. 1987: Rilievi riadiologici nelle scoliosi idiopatiche. Interpretazione etiopatogenetica. Radiol. Med. 73: 271-276

MAREŠ, P. 1991: Epileptic phenomena in the immature brain. Physiol Res. 40: 577-584

MATOUŠKOVÁ, O., CHALUPA, J., CÍGLER, M, HRUŠKA, K. 1992: STAT plus - uživatelská příručka, VÚVeL Brno, 168 p.

MILLNER, P. A., DICKSON, R. A. 1996: Idiopathic scoliosis: biomechanics and biology. Eur. Spine J. 5: $362-$ 373

MOCHIDA, J., BENSON, D. R., ABBOTT, U. R., RUCKER, R. B. 1993: Neuromorphometric changes in the ventral spinal roots in a scoliotic animal. Spine. 18: 350-355

MURRAY, D. W., BULSTRODE, C. J. 1996: The development of adolescent idiopathic scoliosis. Eur. Spine J. 5: 251-257

NOONAN, K. J., WEINSTEIN, S. L., JACOBSON, W. C., DOLAN, L. A. 1996: Use of the Milwaukee brace for progressive idiopathic scoliosis. J. Bone Joint Surg. Am. 78: 557-567

O'BEIRNE, J., GOLDBERG, C., DOWLING, F. E., FOGARTY E. E. 1989: Equilibrial dysfunction in scoliosis - cause or effect? J. Spinal Disord. 2: 184- 189 
PAL, G. P. 1991: Mechanism of Production of Scoliosis. A Hypothesis. Spine. 16: 288-292

PAL, G. P., BHATT, R. H., PATEL, V. S. 1991: Mechanism of production of experimental scoliosis in rabbits. Spine 16: $137-142$

PINCOTT, J. R., DAVIES, J. S., TAFFS, L. F. 1984: Scoliosis caused by section of dorsal spinal nerve roots, J. Bone and Joint Surg. 66: 27-29

ROTH, M. 1996: Idiopatická skolióza - proč právě dolní hrudní ? Vysvětlení z neurovertebrálního vývojového vztahu. Acta Chir. Orthop. Traumatol. Čechosl. 63: 197- 207

ROYO-SALVADOR, M. B. 1996: Siringomielia, escoliosis y malformacion de Arnold-Chiari idiopaticas. Etiologia comun. Rev. Neurol. 24: 937-959

SAHLSTRAND, T., PETRUSON, B., ORTENGREN, R. 1979: Vestibulospinal reflex activity in patients with adolescent idiopathic scoliosis. Acta Orthop. Scand. 50: 275-281

SAMUELSSON, L., LINDELL, D., KOGLER, H. 1991: Spinal cord and brain stem anomalies in scoliosis. MR screening of 26 cases. Acta Orthop. Scand. 62: $403-406$

SEVASTIK, J. A., AARO, S., NORMELLI, H. 1984: Scoliosis. Experimental and clinical studies. Clin. Orthop.191: $27-34$

STEBBINS, R. C. 1960: Effects of pinealectomy in the western fence lizard: Scelopoius occidentalis. Copeia 4 276-283

SUK, S. I., SONG, H. S., LEE, C. K. 1989: Scoliosis induced by anterior and posterior rhizotomy. Spine 14: 692697

TOMASCHEWSKI, R. 1989: Die idiopathische Skoliose in der Sagittalebene. Beitr Orthop Traumatol. 36: 520529

UTIGER, R. D. 1992: Melatonin: The hormone of darkness. New Eng. J. Med. 327: 1377-1379

WAN, Q. I., PANG, S. F. 1994: Segmental, coronal and subcellular distribution of 2-(125I) iodo melatonin binding sites in the chicken spinal cord. Neurosci Lett. 180: 253-256

WANG, X., JIANG, H., RASO, J., MOREAU, M., MAHOOD, J., ZHAO, J., BAGNALL, K. 1997: Characterization of the scoliosis that develops after pinealectomy in the chicken and comparison with adolescent idiopathic scoliosis in humans. Spine. 22: 2626-2635

WORTHINGTON, V., SHAMBAUGH, P. 1993: Nutrition as an environmental factor in the etiology of idiopathic scoliosis. J. Manipulative Physiol. Ther. 16: 169-173

WYATT, M. P., BARRACK, R. L., MUBARAK, S. J., WHITECLOUD, T. S., BURKE, S. W. 1986: Vibratory response in idiopathic scoliosis. J. Bone Joint Surg. 68: 714-718

WYNNE-DAVIES, R., LITTLEJOHN, A., GORMLEY, J. 1982: Aetiology and interrelationship of some common skeletal deformities. (Talipes equinovarus and calcaneovalgus, metatarsus varus, congenital dislocation of the hip, and infantile idiopathic scoliosis), J. Med. Genet. 19: 321-328

ZADEH, H. G., SAKKA, S. A., POWELL, M. P., MEHTA, M. H. 1995: Absent superficial abdominal reflexes in children with scoliosis. An early indicator of syringomyelia. J. Bone Jt. Surg. 77: 762-767 
Plate XII
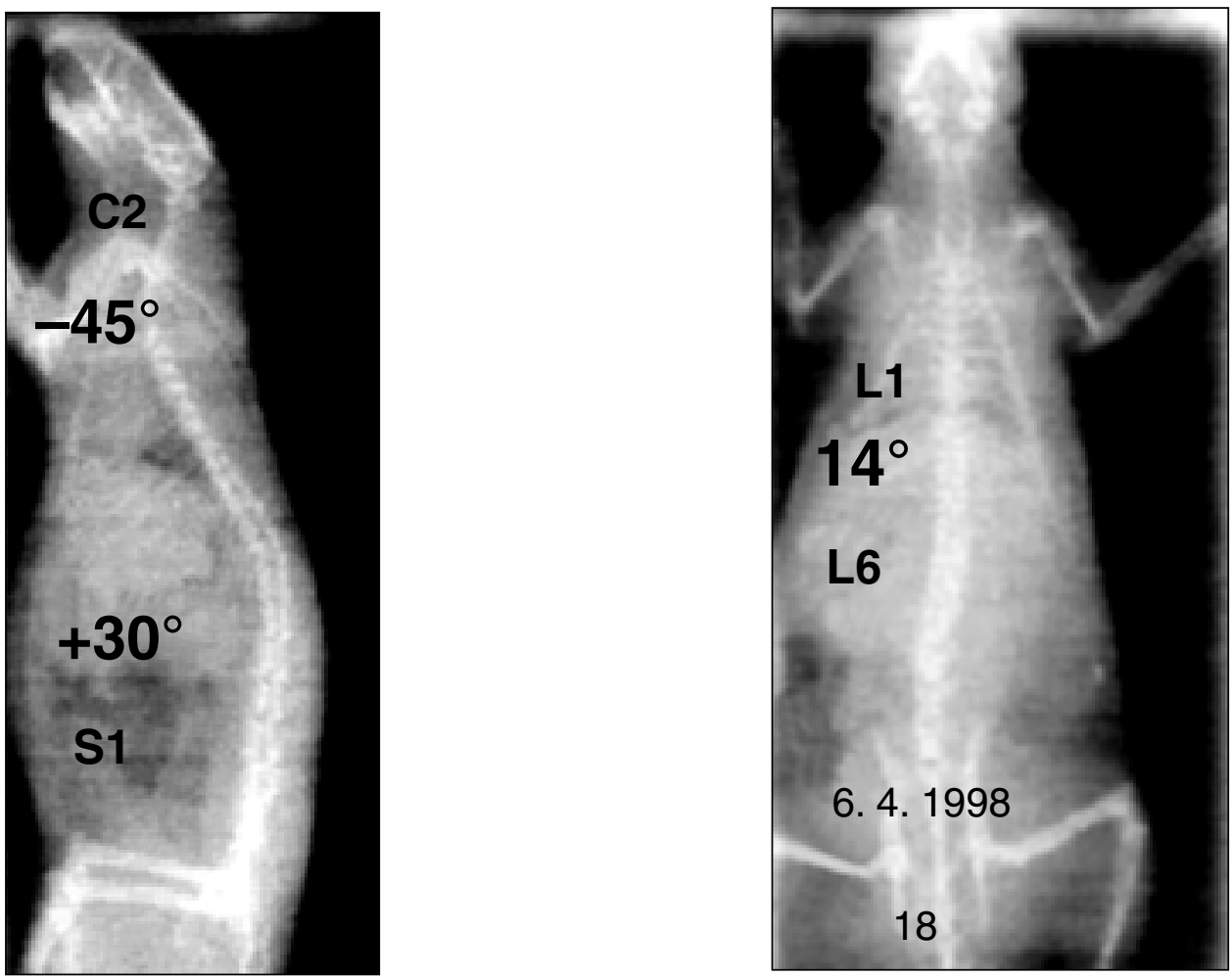

Fig. 1: Rat No. 18. Laterolateral (cervicothoracic lordosis of $-45^{\circ}$ between $\mathrm{C} 2$ and $\mathrm{T} 7$ and thoracolumbar kyphosis $+30^{\circ}$ between T7 and S1) and dorsoventral (left-hand scoliosis of $14^{\circ}$ between L1 and L6) radiographs 4 weeks after the surgical procedure. 